\title{
Litter decomposition and the degradation of recalcitrant components in Pinus massoniana plantations with various canopy densities
}

\author{
Jie Zhang ${ }^{1} \cdot$ Danju Zhang ${ }^{1} \cdot$ Zhang Jian $^{1} \cdot$ Hongyang Zhou $^{1} \cdot$ Yanbo Zhao $^{1} \cdot$ \\ Daping Wei ${ }^{1}$
}

Received: 7 November 2017/ Accepted: 4 February 2018/Published online: 11 June 2018

(C) The Author(s) 2018

\begin{abstract}
To understand the decomposition characteristics of Pinus massoniana foliar litter and the degradation of its refractory compounds in plantations under five canopy densities, a litter bag experiment over a decomposition time of 392 days was carried out. The results show that canopy density significantly affected decomposition rates of litter and degradation rate of lignin and cellulose. Litter decomposition rates decreased significantly with decreasing canopy density. Both lignin and cellulose degradation rates were lower with canopy densities of 0.62 and 0.74 as compared with the three other densities. Lignin and cellulose losses were more rapid in the first 118 days. Soil fauna had significant impacts on litter decomposition and the degradation of refractory compounds. Canopy density had significant effects on factors such as soil properties and soil fauna community structure, which could be conducive to the decomposition of litter and the degradation of litter recalcitrant components. Canopy density between 0.6 and 0.7 might be a favorable management practice promoting
\end{abstract}

Project funding: The work was supported by the National Natural Science Foundation of China (Grant Number 31370628), the National Science and Technology Support Project of China (Grant Number 2011BAC09B05), the Sichuan Provincial Science and Technology Support Project (Grant Number 12ZC0017).

The online version is available at http://www.springerlink.com

Corresponding editor: Chai Ruihai.

Zhang Jian

sicauzhangjian@163.com

1 Key Laboratory of Ecological Forestry Engineering of Sichuan Province, Institute of Ecology and Forestry, Sichuan Agriculture University, Chengdu 611130, People's Republic of China litter decomposition and beneficial for the sustainable development of $P$. massoniana plantations.

Keywords Pinus massoniana · Canopy density · Litter decomposition $\cdot$ Lignin $\cdot$ Cellulose

\section{Introduction}

Litter decomposition is one of the most important ecological processes contributing to nutrient cycling in forests, and an important link between the material cycle and energy flows (Berg and McClaugherty 2008; Herman et al. 2008).Litter decomposition includes easily decomposed components as well as material resistant to decomposition. The early stages of decomposition of foliar litter is predominantly a fast, physical leaching process (Wu et al. 2010) during which water-soluble components and a small amount of labile organic components are degraded (Couteaux et al. 1995). During the late stages, decomposition is mainly by biodegradation. Organic components that are difficult to break down (lignin, cellulose) begin to decompose (Berg and McClaugherty 2008). Decomposition of recalcitrant or persistent components is a key process in the turnover and cycling of nutrients in forest ecosystems, which also control the decomposition rate and percentage (Schwarz 2001; Rahman et al. 2013). Compared with broad-leaved tree species, the needles of conifers contain more recalcitrant secondary metabolites such as cellulose, hemicelluloses, lignin, and tannins (Guo et al. 2009).

Canopy density, an important factor that reflects the forest environment and structure ( $\mathrm{Li}$ et al. 2008), has a significant influence on understory plant diversity, soil biota community structure, and understory environmental 
heterogeneity (Flukes et al. 2014). Canopy openness is a major driver of species composition due to its correlation with the amount of light that can penetrate to the understory (Battaglia et al. 2002), thus affecting plant diversity, litter decomposition, and soil microbial community structure, all of which affect forest structure and function (Hossain and Sugiyama 2011). Although forest management and ecological research associated with canopy density has recently gained more attention (Zhou et al. 2013; Madsen and Larsen 1996; Liu et al. 2011; Fu et al. 2014), there remains a scarcity of information on litter decomposition characteristics in plantations related to canopy density.

Pinus massoniana Lamb, one of the most widely distributed conifers in the low mountainous regions in the upper and middle Yangtze River areas in China, has become the most important coniferous plantation species due to its fast growth and environmental adaptability. P. massoniana plantations cover more than two million ha and occupy a large proportion of the plantation forests in China (SFA 2013). However, due to monoculture management over large areas and unreasonable harvest methods, $P$. massoniana plantations have generated a series of ecological problems such as low productivity (Shen 1995), soil degradation (Tan et al. 2013), pests and diseases (Tong et al. 2014), and lower biodiversity (Cui et al. 2014). Therefore, more effective management practices of these plantations are needed to ensure their sustainable development. At present, plantation management includes thinning and tending (Tsai et al. 2011; Lin et al. 2010), producing forest gaps (Zhang et al. 2015), and density control (Wang 2012). Limited information is available on the effects of canopy density on forest ecosystem processes.

The purpose of this study was to assess the characteristics of litter degradation and its two recalcitrant components, lignin and cellulose, over a 392-day period in plantations with different canopy densities Additionally, we aimed to identify a favorable canopy density that would facilitate the decomposition of litter and hypothesized that litter degradation changes significantly under various canopy densities. Intermediate canopy density might be favorable for litter degradation including the degradation of recalcitrant compounds. This study will provide insight into nutrient cycling processes in plantations when controlling canopy density.

\section{Materials and methods}

\section{Study site}

The site was located in Maodianao forest compartment VI, Forest Management in Laifu Town, Gaoxian County, Yibin City, Sichuan Province $\left(104^{\circ} 21^{\prime}-104^{\circ} 48^{\prime} \mathrm{E}, \quad 28^{\circ} 11^{\prime}-\right.$ $28^{\circ} 47^{\prime} \mathrm{N}$; Fig. 1) with altitudes of 412 masl to 567 masl. The region experiences a subtropical humid monsoon climate with abundant rainfall and a hot rainy season with an annual average temperature of $18.1^{\circ} \mathrm{C}$. Annual average rainfall is $1021.8 \mathrm{~mm}$ with a clear distinction between rainy and dry seasons. Abundant rainfall occurs from June to November with less between January to April (Zhang et al. 2014). Relative humidity is often more than $80 \%$ and the annual duration of sunshine is $1148 \mathrm{~h}$. The soil is a mountain yellow soil and the bedrock is yellow sandstone.

\section{Experimental design}

An 11-year-old $P$. massoniana plantation with a canopy density of 0.91 and $1.5 \mathrm{~m}$ spacing was the basis for the canopy control experiment. Canopy densities were determined using a CI-110 instrument along a test square within each site. By thinning the stems and branches, a canopy density gradient was created with densities of 0.91 (A), 0.83 (B), 0.74 (C), 0.62 (D), and 0.49 (E). Each density gradient had three sample sites (Fig. 1). The area of each site was $20 \mathrm{~m} \times 20 \mathrm{~m}$, the distance between sites $10 \mathrm{~m}$, and the distance from the sampling site to the edge of the forest $10 \mathrm{~m}$. To ensure site densities were maintained, branches were thinned when required. After controlling the canopy density, a descriptive survey of the sampling sites was undertaken in June 2014 (Table 1). Soil physical and chemical properties were also determined.

\section{Litter decomposition}

In June 2014, recently fallen needles of $P$. massoniana were collected from the forest floor under the site with a canopy density of 0.91 . The needles were air-dried at room temperature for more than 2 weeks before being ovendried at $65{ }^{\circ} \mathrm{C}$ for $48 \mathrm{~h}$ to determine air-dried and ovendried needle mass ratio. This ratio was used to convert the initial air-dried mass to its oven-dried mass (He et al. 2015). Subsamples of the needles were ground, sieved at $0.2 \mathrm{~mm}$, and analyzed to determine the initial quality of the litter (Table 2). Samples (10 g of dry weight) were put in $20 \times 20 \mathrm{~cm}$ nylon bags with $0.5 \mathrm{~mm}$ mesh on each side, and placed on the sampling sites at the end of June 2014 to quantify foliar litter, lignin and cellulose degradation. The 900 bags were placed on the forest floor from the center of 
Fig. 1 Three sites per plot density $\left(A_{1}, A_{2}, A_{3}\right)$ were selected as replicates. The area of each canopy density site was a standard $20 \times 20 \mathrm{~m}$, the distance between sites $10 \mathrm{~m}$, and the distance from the site to the edge of the forest $10 \mathrm{~m}$

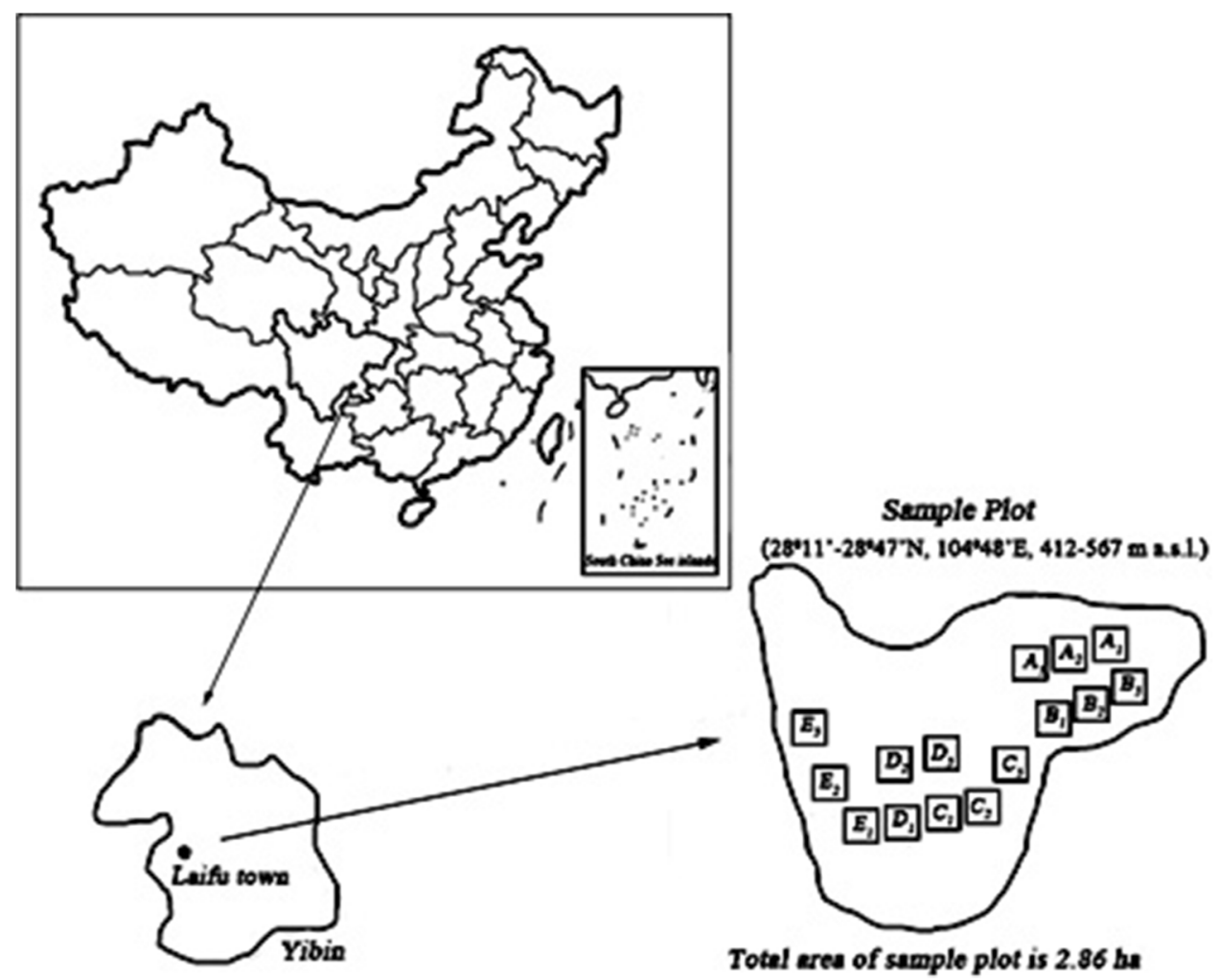

Table 1 Description of sampling sites, soil physical and chemical properties (mean $\pm \mathrm{SE}, \mathrm{n}=3$ )

\begin{tabular}{|c|c|c|c|c|c|c|c|c|c|}
\hline $\begin{array}{l}\text { Plantation } \\
\text { plots }\end{array}$ & $\begin{array}{l}\text { Altitude } \\
(\mathrm{m})\end{array}$ & $\begin{array}{l}\text { Slope/ } \\
\left({ }^{\circ}\right)\end{array}$ & $\begin{array}{l}\text { Slope } \\
\text { location }\end{array}$ & \multicolumn{2}{|c|}{ Aspect } & \multicolumn{2}{|c|}{$\begin{array}{l}\text { Mean diameter at breast height } \\
(\mathrm{cm})\end{array}$} & $\begin{array}{l}\text { Moisture content } \\
(\%)\end{array}$ & Soil $\mathrm{pH}$ \\
\hline $\mathrm{A}$ & 453.4 & 29 & Mid-slope & \multicolumn{2}{|l|}{ SE } & \multicolumn{2}{|c|}{$10.16 \pm 2.81$} & $22.98 \pm 1.08 \mathrm{a}$ & $3.98 \pm 0.03 b$ \\
\hline B & 457.2 & 30 & Mid-slope & \multicolumn{2}{|l|}{ SE } & \multicolumn{2}{|c|}{$10.16 \pm 1.99$} & $20.23 \pm 1.10 \mathrm{ab}$ & $4.00 \pm 0.01 b$ \\
\hline $\mathrm{C}$ & 462.9 & 29 & Mid-slope & \multicolumn{2}{|l|}{ SE } & \multicolumn{2}{|c|}{$10.38 \pm 1.82$} & $21.90 \pm 1.23 \mathrm{ab}$ & $3.97 \pm 0.01 b c$ \\
\hline $\mathrm{D}$ & 453.6 & 26 & Mid-slope & \multicolumn{2}{|l|}{ SE } & \multicolumn{2}{|c|}{$10.87 \pm 2.30$} & $19.64 \pm 0.29 b$ & $4.08 \pm 0.03 a$ \\
\hline $\mathrm{E}$ & 483.6 & 30 & Mid-slope & SW & & \multicolumn{2}{|c|}{$11.56 \pm 2.04$} & $20.00 \pm 0.56 b$ & $3.91 \pm 0.01 \mathrm{c}$ \\
\hline $\begin{array}{l}\text { Plantation } \\
\text { plots }\end{array}$ & $\begin{array}{l}\text { Soil bulk } \\
\text { density } \\
\left(\mathrm{g} \mathrm{cm}^{-3}\right)\end{array}$ & $\begin{array}{l}\text { Carbon } \\
\left(\mathrm{g} \mathrm{kg}^{-1}\right)\end{array}$ & $\begin{array}{l}\text { Nitrogen } \\
\left(\mathrm{g} \mathrm{kg}^{-1}\right)\end{array}$ & & & $\begin{array}{l}\text { phorus } \\
(-1)\end{array}$ & $\begin{array}{l}\text { Temperature in } \\
\text { ambient foliar } \\
\text { litterbags }\end{array}$ & $\begin{array}{l}\text { Soil faunal } \\
\text { Shannon } \\
\text { diversity index }\end{array}$ & $\begin{array}{l}\text { Soil faunal } \\
\text { individual density } \\
\text { (ind } \mathrm{m}^{-2} \text { ) }\end{array}$ \\
\hline A & $1.37 \pm 0.04$ & $16.07 \pm 0.88$ & $1.03 \pm 0$ & & & $\pm 0.01 \mathrm{ac}$ & $17.16 \pm 0.07 b$ & $1.66 \pm 0.15 \mathrm{a}$ & $105,769.01 \pm 0.11 \mathrm{a}$ \\
\hline $\mathrm{B}$ & $1.36 \pm 0.60$ & $12.64 \pm 0.921$ & $0.73 \pm 0.0$ & & $0.1^{\prime}$ & $7 \pm 0.02 b c$ & $17.39 \pm 0.04 a b$ & $1.63 \pm 0.18 \mathrm{ab}$ & $88,451.94 \pm 0.21 b$ \\
\hline $\mathrm{C}$ & $1.36 \pm 0.05$ & $15.67 \pm 1.33$ & ab $\quad 0.94 \pm 0.0$ & $4 a b$ & 0.2 & $4 \pm 0.02 \mathrm{a}$ & $17.35 \pm 0.06 \mathrm{ab}$ & $1.63 \pm 0.27 \mathrm{ab}$ & $90,541.81 \pm 0.15 \mathrm{ab}$ \\
\hline $\mathrm{D}$ & $1.39 \pm 0.04$ & $12.56 \pm 1.231$ & $0.77 \pm 0.0$ & & 0.1 & $5 \pm 0.01 b$ & $17.34 \pm 0.03 \mathrm{ab}$ & $1.57 \pm 0.30 \mathrm{~b}$ & $82,639.31 \pm 0.16 b$ \\
\hline $\mathrm{E}$ & $1.31 \pm 0.05$ & $17.92 \pm 0.46$ & $0.91 \pm 0.0$ & & 0.1 & $5 \pm 0.01 b$ & $17.80 \pm 0.03 \mathrm{a}$ & $1.63 \pm 0.21 \mathrm{ab}$ & $85,500.97 \pm 0.16 b$ \\
\hline
\end{tabular}

Different lowercase letters indicate a significant difference between species within the same variable (independent samples $\mathrm{t}$ test, $P<0.05$ )

Canopy density of $\mathrm{A}\left(0.91 \pm 0.02\right.$, average of $\left.\mathrm{A}_{1}, \mathrm{~A}_{2}, \mathrm{~A}_{3}\right)$. Canopy density of $\mathrm{B}\left(0.83 \pm 0.05\right.$, average of $\left.\mathrm{B}_{1}, \mathrm{~B}_{2}, \mathrm{~B}_{3}\right), \mathrm{Canopy}_{\mathrm{a}} \mathrm{density}$ of $\mathrm{C}$ $\left(0.74 \pm 0.02\right.$, average of $\left.\mathrm{C}_{1}, \mathrm{C}_{2}, \mathrm{C}_{3}\right)$, Canopy density of $\mathrm{D}\left(0.62 \pm 0.01\right.$, average of $\left.\mathrm{D}_{1}, \mathrm{D}_{2}, \mathrm{D}_{3}\right)$, Canopy density of $\mathrm{E}(0.49 \pm 0.08$, average of $\left.\mathrm{E}_{1}, \mathrm{E}_{2}, \mathrm{E}_{3}\right)$; SE: southeast, SW: southwest. These data were measured after controlling the canopy density for 392 days

the site to the edge (60 bags per site). Each site had five litter bag positions (center, east, west, north and south edges) at intervals of $3 \mathrm{~m}$ to ensure adequate micro-environmental conditions. A 2-cm space was left between the bags so they did not interfere with each other. To record the ambient temperature of the litter bags, iButton Recorders (DS1402D-DR8 + 11221A1, CHN) were placed in one litter bag at each sample center. Temperatures were recorded every $2 \mathrm{~h}$. 
To quantify lignin and cellulose degradation, the litter bags were sampled 12 times over a 1-year period, randomly collected from five positions on each sampling date. At the same time, collected samples had soil carefully removed before being placed into sterilized polyethylene bags. All samples were labeled, taken to the laboratory where litter was removed and oven dried at $65{ }^{\circ} \mathrm{C}$ until a constant weight. The samples were crushed and sieved $(0.2 \mathrm{~mm})$, and the litter weighed to calculate the percentage loss. Lignin and cellulose concentrations were determined according to the acid detergent lignin method, with some modifications ( $\mathrm{He}$ et al. 2016a).

Oven dried samples, (dried at $65{ }^{\circ} \mathrm{C}$ for $48 \mathrm{~h}$ to determine dry mass), were analyzed for carbon, nitrogen, and phosphorus concentrations. Carbon levels were determined using the dichromate oxidation-sulfate-ferrous titration method. Sub-samples of $0.2 \mathrm{~g}$ were acid-digested with a solution of $8 \mathrm{~mL} \mathrm{H}_{2} \mathrm{SO}_{4}\left(\rho=1.84 \mathrm{~g} \mathrm{~cm}^{-3}\right)$ and $3 \mathrm{~mL}$ $\mathrm{H}_{2} \mathrm{O}_{2}$ at $190{ }^{\circ} \mathrm{C}$ for $30 \mathrm{~min}$. The solution was transferred to a $100 \mathrm{~mL}$ volumetric flask, quantified, filtered, and stored for $\mathrm{N}$ and $\mathrm{P}$ analyses using indophenol-blue colorimetry and phosphomolybdenum-yellow colorimetry, respectively (He et al. 2016b).

\section{Soil properties analyses}

Soil samples taken at a depth of $10 \mathrm{~cm}$ were collected in May 2013 from the same five points in accordance with the litter bags. Samples were mixed, air dried, weighed, and passed through a $0.2 \mathrm{~mm}$ sieve. Moisture content, bulk density, and $\mathrm{pH}$ were determined using standard analysis methods and carbon, nitrogen, and phosphorus concentrations were determined according to Lu (1999).

\section{Soil fauna collection}

Five $50 \mathrm{~cm} \times 50 \mathrm{~cm}$ plots, (center, east, west, north and south edges) were established in each site to collect the soil fauna in three layers, the litter layer, upper 5-cm layer, and the $5-10 \mathrm{~cm}$ layer.

Macro fauna ( $>2 \mathrm{~mm}$ ) were collected by hand from the three layers. The collections were put into a centrifuge tube with alcohol and taken to the laboratory for identification. Soil samples for the identification of meso-micro fauna were also collected from the three layers in the five points using a cylindroids sample collector. Litter was collected within $10 \mathrm{~cm} \times 10 \mathrm{~cm}$ area to obtain the fauna. Soil and litter samples were put into black cloth bags, taken to the laboratory, and meso/micro soil fauna separated by Baermann's method and Tullgren's method, respectively. Both macro and meso/micro fauna were classified according to Yi (1998). 


\section{Statistical analyses}

The exponential decay model by Olson(1963) was used to fit the relationship between the litter decomposition rates (y), lignin and cellulose degradation rates with the decomposition time (t).

The decomposition model : $M_{t} / M_{0}=a * e^{-k t}$

where $M_{t}$ is the foliar litter dry weight $(\mathrm{g})$ at time $(\mathrm{t}) ; M_{0}$ the initial dry weight $(\mathrm{g})$ of the foliar litter; $a$ the fitting parameter; $k$ the annual decomposition rate of the foliar litter $\left(\mathrm{yr}^{-1}\right)$ :

$\mathrm{L}_{\mathrm{t}} / \mathrm{R}_{\mathrm{t}}(\%)=\left[\mathrm{M}_{\mathrm{L} / \mathrm{R}}(\mathrm{t}-1)-\mathrm{M}_{\mathrm{L} / \mathrm{R}} \mathrm{t}\right] / \mathrm{M}_{0} \times 100$

where $\mathrm{M}_{\mathrm{L} / \mathrm{R}} \mathrm{t}$ and $\mathrm{M}_{\mathrm{L} / \mathrm{R}}(\mathrm{t}-1)$ are the remaining lignin or cellulose contents between the current and previous sampling dates, respectively; $\mathrm{M}_{0}$ is the initial lignin or cellulose content.

Soil fauna Shannon diversity index and soil fauna richness index were calculated using the following:

Shannon diversity index $\left(H^{\prime}\right): H^{\prime}=-\sum_{i=1}^{s} P_{i}\left(\ln P_{i}\right)$

Margalef richness index (D) : $\mathrm{D}=(S-1) / \ln N$

where $P_{i}=N_{i} / N ; N$ is the total group numbers in the community; $S$ the number of groups; $N_{i}$ the $i$ groups individual number.

The response of litter decomposition characteristics to time in plantations under various canopy densities were evaluated using an exponential regression. ANOVA tests evaluated both the effects of canopy density and time on litter decomposition rates, and lignin and cellulose degradation rates. One-way ANOVA tests were conducted to evaluate the effects of canopy density on the understory environment and soil fauna. After verifying the general ANOVA and one-way ANOVA hypothesis, detailed post hoc mean comparisons for the significant differences in litter variables were performed using Tukey's honest significant difference (HSD) test. The homogeneity of the variances was tested using Levene's test. Any datasets failing this test were log-transformed before further analysis to help satisfy the requirement of variance homogeneity. All analyses were performed using the Statistical Product and Service Solutions program (SPSS 17.0), and Origin 9.0 was used to draw the graphs.

\section{Results}

\section{Effect of canopy densities on understory environment}

The one-way ANOVA showed that understory environmental factors and soil faunal diversity indices changed significantly under various canopy densities except for temperatures of the ambient foliar litter (Table 3).

\section{Litter decomposition characteristics}

The ANOVA showed that litter decomposition rates and the degradation rates of lignin and cellulose were significantly affected by canopy densities and decomposition times (Table 4). The litter decomposition rates, according to densities, were: $\mathrm{E}(k=0.518)>\mathrm{D}(k=0.478)>\mathrm{C}$ $(k=0.477)>\mathrm{B}(k=0.0468)>\mathrm{A}(k=0.384)$. Decomposition rates increased significantly with decreasing canopy density; there were no significant changes to rates in densities B, C and D (Fig. 2a). The rate under density E was significantly lower than rates under the other densities. The percentage of the remaining litter to the initial mass was $63.8,63.0,62.0,61.9$, and $60.4 \%$ over a decreasing density (A, B, C, D, and E), respectively. Over the decomposition period, there were no significant changes to the remaining litter initially with densities A-D, but density E showed a significant decrease in remaining litter (Fig. 3a).

\section{Lignin and cellulose degradation characteristics}

Canopy densities and decomposition times significantly impacted lignin and cellulose degradation (Table 4). Lignin degradation was ranked as the following: D $(k=0.478)>\mathrm{C} \quad(k=0.445)>\mathrm{E} \quad(k=0.442)>\mathrm{A}$ $(k=0.384)>\mathrm{B} \quad(k=0.373)$. Cellulose degradation rate was $\mathrm{D}(k=1.076)>\mathrm{C}(k=1.055)>\mathrm{E}(k=0.916)>\mathrm{B}$ $(k=0.847)>\mathrm{A} \quad(k=0.772)$. Both lignin and cellulose degradation rates under $\mathrm{C}$ and $\mathrm{D}$ canopies were significantly higher than the others (Fig. 2b, c). The lignin concentrations under C and D canopy densities decreased significantly during the first 118 days, and then increased significantly over the remainder of the degradation time (Fig. 3b). Lignin concentrations of litter under A and B canopy densities increased significantly over time; the lignin concentrations of canopies $\mathrm{C}$ and $\mathrm{D}$ were significantly different from canopies A, B, and E. The lignin concentrations in canopies $\mathrm{C}$ and $\mathrm{D}$ were the lowest during the degradation time. Cellulose levels in all canopies showed an exponentially decreasing trend over the degradation time; the concentrations decreased rapidly during the first 118 days, and slowed after this period (Fig. 3c). 
Cellulose concentrations under canopies $\mathrm{C}$ and D were significantly different from those under canopies A, B and E. The Cellulose concentrations in canopies $\mathrm{C}$ and $\mathrm{D}$ were the lowest during the degradation time.

The remaining lignin in the litter showed an exponentially decreasing trend over the degradation (Fig. 3d). The percentage of lignin remaining compared to the initial lignin in the litter was $68.4,69.0,64.9,62.3$, and $65.5 \%$ for canopy densities A to E, respectively. Lignin loss mainly occurred during the first 118 days; the percentage lost compared to the total period was more than $72 \%$ regardless of the canopy density (Fig. 4a). Lignin remaining in the litter under canopies $\mathrm{C}$ and $\mathrm{D}$ was significantly different than under canopies A, B and E. The lignin decomposed faster under $\mathrm{C}$ and $\mathrm{D}$ canopies than under $\mathrm{A}, \mathrm{B}$, and $\mathrm{E}$. Over the experimental period, the remaining cellulose in the litters showed an exponentially decreasing trend over the degradation time (Fig. 3e). The percentages of cellulose loss were 53.9, 51.7, 44.3, 44.0 and $49.4 \%$, respectively, under canopy densities A-E. The cellulose loss in the litter mainly occurred during the first 118 days (Fig. 4b) and accounted for more than $68 \%$ regardless of canopy density. The remaining cellulose under $\mathrm{C}$ and $\mathrm{D}$ canopies was significantly different than under A, B and E canopies. The cellulose broke down faster under the middensity canopies $\mathrm{C}$ and $\mathrm{D}$ than under the other canopies.

\section{Discussion}

This study shows that litter decomposition rates, and lignin and cellulose degradation rates were significant affected by temperature in ambient foliar litter and soil fauna (Table 5), and that litter decomposition under canopy E, (density 0.49), was the highest than under the other canopies. Lignin and cellulose degradation rates were highest under canopy D (density 0.62 ). The litter in the remaining mass decreased exponentially over the decomposition time, which also decreased with the decreasing canopy density. Lignin and cellulose decomposed faster under mid canopy densities C (0.74) and D (0.62). The present results partially support our hypothesis that litter degradation changes significantly under various canopy densities. Intermediate canopy density might be favorable for litter.

In this study, litter decomposition was highest under canopy E. The remaining litter decreased exponentially over the decomposition time, and was significantly lower than under the other canopies (Fig. 3a). Under natural conditions, litter decomposition requires three processes: atmospheric leaching, crushing, and biodegradation, among which biodegradation is the most important. At the early stage of decomposition, atmospheric leaching and crushing have significant impacts on litter decomposition (Wu et al. 2010); biodegradation is the dominant factor in late decomposition (Simoneta et al. 2008; Wall et al. 2008). There were no significant differences among canopy densities A, B, C, and D on the remaining litter; however, the rate of decomposition was faster in plantations with the lowest canopy density (E). Soil fauna had significant influence on the decomposition rates (Table 5). Temperature also influenced the decomposition rates but there were no significant changes among the various densities. Canopy density also affected the understory environment. Light and water conditions were optimal in plantations with the lowest canopy density (Zhao et al. 2017). The understory grew rapidly, forming shade to protect the foliar litter from temperature increases. For this the temperature in ambient foliar litter had no differences with the various canopy density. In the first 118 days, higher temperatures and larger amounts of precipitation during the summer accelerated the leaching of the organic matter and carbohydrate decomposition on all sites. These factors led to faster

Table 3 Results of one-way ANOVA of canopy density on soil factors and soil fauna

\begin{tabular}{|c|c|c|c|c|c|c|}
\hline & $\begin{array}{l}\text { Temperature in } \\
\text { ambient foliar } \\
\text { litter }\end{array}$ & Soil carbon & Soil nitrogen & Soil phosphorus & $\begin{array}{l}\text { Macro soil } \\
\text { faunal } \\
\text { individual } \\
\text { density }\end{array}$ & $\begin{array}{l}\text { Meso/micro soil } \\
\text { faunal individual } \\
\text { density }\end{array}$ \\
\hline \multirow{2}{*}{$\begin{array}{l}\text { Canopy } \\
\text { density }\end{array}$} & 37.886 & $37.782 * *$ & $3.256 * *$ & $3.563 * *$ & $154.630 *$ & $234.77 * *$ \\
\hline & $\begin{array}{l}\text { Meso/micro soil } \\
\text { faunal richness } \\
\text { index }\end{array}$ & $\begin{array}{l}\text { Understory plant } \\
\text { Shannon-wiener } \\
\text { species diversity index }\end{array}$ & $\begin{array}{l}\text { Macro soil faunal } \\
\text { Shannon } \\
\text { diversity index }\end{array}$ & $\begin{array}{l}\text { Meso/micro soil } \\
\text { faunal Shannon } \\
\text { diversity index }\end{array}$ & $\begin{array}{l}\text { Macro soil } \\
\text { faunal } \\
\text { richness index }\end{array}$ & \\
\hline $\begin{array}{l}\text { Canopy } \\
\text { density }\end{array}$ & $1.376 * *$ & $81.938 * *$ & $230.76^{*}$ & $143.66 * *$ & $11.345^{*}$ & \\
\hline
\end{tabular}

Significant effects: $* P<0.05 ; * * P<0.01$ 
Table 4 Results of ANOVA on the effects of canopy density and decomposing time on litter decomposition rates, and lignin and cellulose degradation rates

\begin{tabular}{lccc}
\hline & Litter decomposition rate & Lignin degradation rate & Cellulose degradation rate \\
\hline Canopy density & $0.467^{*}$ & $6.330^{* *}$ & $0.351^{*}$ \\
Canopy density $\times$ time & $21.334^{* *}$ & $13.844^{* *}$ & $15.244^{* *}$ \\
\hline
\end{tabular}

Significant effects: $* P<0.05 ; * * P<0.01$
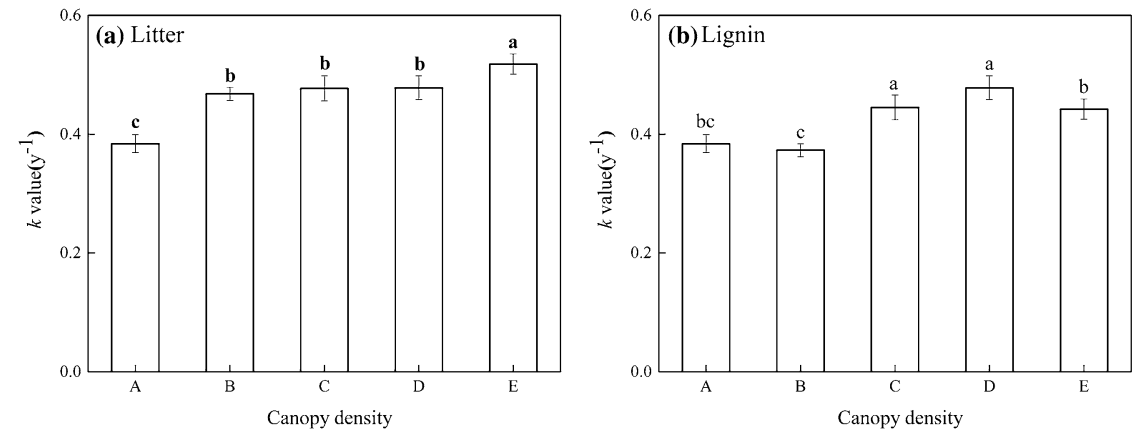

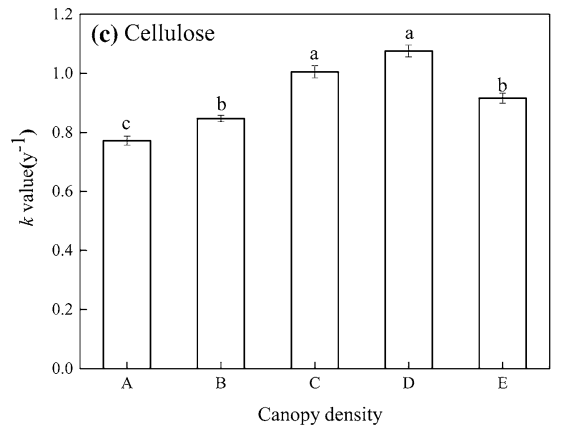

Fig. 2 Decay constant $\left(\mathrm{k}, \mathrm{y}^{-1}, \mathrm{r}^{2}, p<0.05\right)$ for litter $(\mathbf{a})$, lignin $(\mathbf{b})$, and cellulose (c) of $P$. massoniana as affected by canopy density in the plantation. A, Canopy density $(0.91 \pm 0.02), \mathbf{B}$, Canopy density $(0.83 \pm 0.05), \mathbf{C}$, Canopy density $(0.74 \pm 0.02), \mathbf{D}$, Canopy density

decomposition rates at the early stages. After 118 days, decomposition rates may have mainly relied on biodegradation through breakdown by soil biota. Our previous studies indicated that the diversity of soil fauna and microbes increased with decreasing canopy density (Zhou et al. 2017). These reasons might explain the influence of canopy density on litter decomposition. Canopy densities, decomposition time, and soil fauna had significant impacts on lignin and cellulose degradation rates (Tables 4, 5). Lignin and cellulose degradation were faster under $\mathrm{C}$ and $\mathrm{D}$ canopy densities than under A, B, and E densities (Fig. 3d, E). Theoretically, temperature and soil fauna are important drivers for litter decomposition, but temperatures of ambient foliar litter in the present study did not differ with canopy density (Table 3). Therefore, degradation was mostly biodegradation. The abundance and activities of decomposers can increase with decreasing canopy density, except for canopy E, causing a decrease in litter lignin and cellulose degradation associated with decreasing density over the decomposition time. The decomposition of recalcitrant components varied with various canopy densities. Both lignin and cellulose significantly decomposed under $\mathrm{C}$ and $\mathrm{D}$ densities. Thinning and pruning optimized the sunlight and moisture levels with decreasing density; however, the foliar litter remaining was greatest in $P$. massoniana plantations under the E canopy, (the least dense), because of more direct sunlight and rain. Our
$(0.62 \pm 0.01)$, E, Canopy density $(0.49 \pm 0.08$,$) . [Values are$ mean \pm SD. Bars indicate the standard error. Different lowercase letters indicate significant differences $(P<0.05)$ among the different canopy density during the decomposition period.]

previous study also found that understory plant diversity was higher in plantations under intermediate densities, but the lowest density resulted in a significantly reduced forest evenness index, indicating low diversity and stability of the understory plants (Zhao et al. 2017). Preliminary studies have also indicated that the diversity of soil fauna and microbes were higher in plantations under $\mathrm{C}$ and $\mathrm{D}$ canopy densities. When canopy density is reduced too much, understory plants and higher temperatures did provide a suitable environment for soil fauna. The conditions were not conducive for maintaining the soil fauna community's diversity and stability (Zhou et al. 2017). This may explain the dynamic changes in decomposition of the recalcitrant compounds in P. massoniana plantations across a range of canopy densities.

Lignin and cellulose loss mainly occurred during the first 118 days under various canopy densities (Fig. 4 a and b). The variations could be related to suitable temperatures and available sunlight and moisture which made the foliar litter more conducive to microbial attachment, leading to accelerated degradation of lignin and cellulose (Brandt et al. 2010). Compared with canopy densities A, B and E, lignin and cellulose losses under mid-level densities $\mathrm{C}$ and $\mathrm{D}$ were faster because of the more active soil fauna levels. Shannon diversity index and richness index were greatest under these canopies and significantly influenced lignin and cellulose loss. At the late stages of degradation, with 

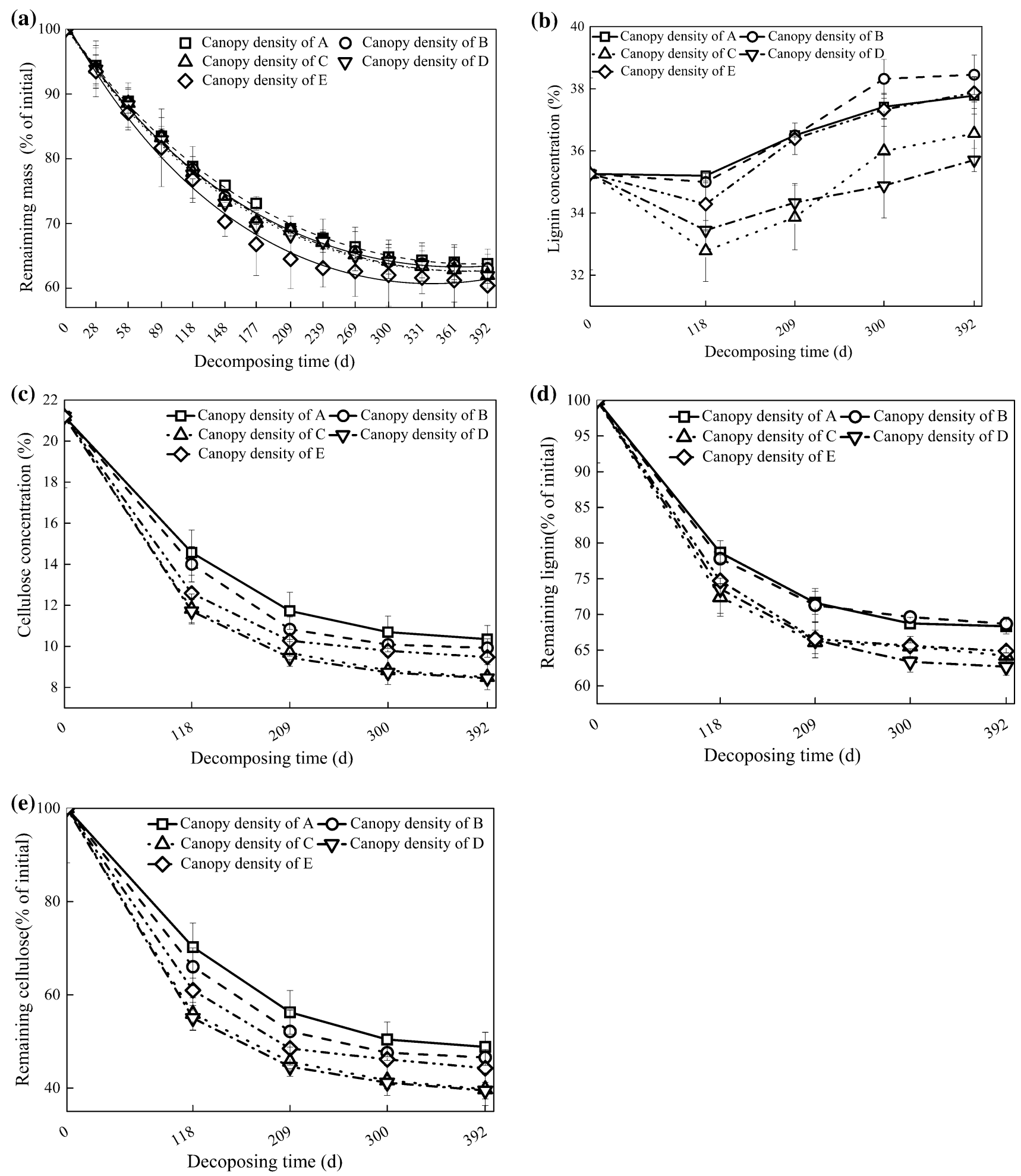

Fig. 3 Effects of canopy densities on the remaining mass (\% of initial) (a), lignin and cellulose concentration (b, c) and remaining lignin and cellulose content (\% of initial) $(\mathbf{d}, \mathbf{e})$ in the foliar litter of $P$. massoniana in the pure P. massoniana plantations from July 23, 2014,

decreasing temperatures in ambient foliar litter, the activity of soil fauna was also reduced. Lignin and cellulose loss rates slow, and the lignin may combine with cellulose to

to July 22, 2015 (a total of 392 days in the field). A Canopy density $(0.91 \pm 0.02)$, B Canopy density $(0.83 \pm 0.05)$, C Canopy density $(0.74 \pm 0.02)$, D Canopy density $(0.62 \pm 0.01)$, E Canopy density $(0.49 \pm 0.08)$

form lignin-cellulose complexes (Austin and Ballaré 2010). This would hinder the degradation of cellulose by 1 fauna and microorganisms, as these complexes slow 


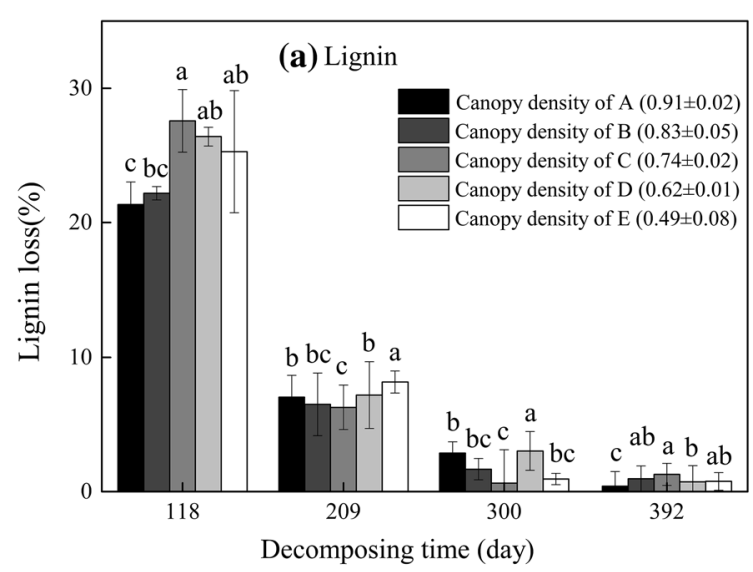

Fig. 4 Effects of canopy densities on lignin (a) and cellulose (b) loss in thepure $P$. massoniana plantations foliar litter during different decomposition times [Bars indicate the standard error. Different

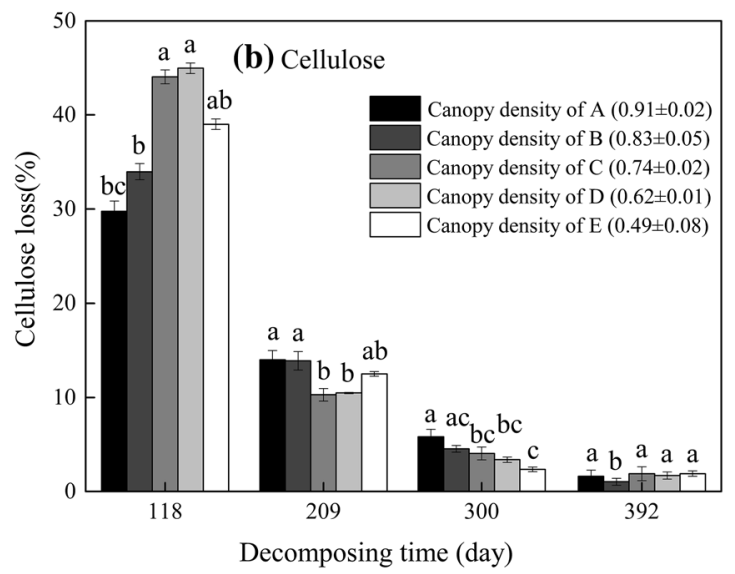

lowercase letters indicate significant differences $(P<0.05)$ among the different canopy density during the same decomposition period]

Table 5 Correlation coefficient (r) between temperature in ambient foliar litter and soil faunal factor with litter decomposition rate, lignin and cellulose degradation rate in the $P$. massoniana plantations

\begin{tabular}{|c|c|c|c|c|c|c|c|}
\hline & $\begin{array}{l}\text { Temperature } \\
\text { in ambient } \\
\text { foliar litter }\end{array}$ & $\begin{array}{l}\text { Macro soil } \\
\text { faunal } \\
\text { individual } \\
\text { density }\end{array}$ & $\begin{array}{l}\text { Meso/micro soil } \\
\text { faunal } \\
\text { individual } \\
\text { density }\end{array}$ & $\begin{array}{l}\text { Macro soil } \\
\text { faunal Shannon } \\
\text { diversity index }\end{array}$ & $\begin{array}{l}\text { Meso/micro soil } \\
\text { faunal Shannon } \\
\text { diversity index }\end{array}$ & $\begin{array}{l}\text { Macro soil } \\
\text { faunal } \\
\text { richness } \\
\text { index }\end{array}$ & $\begin{array}{l}\text { Meso/micro } \\
\text { soil faunal } \\
\text { richness index }\end{array}$ \\
\hline $\begin{array}{l}\text { Temperature in } \\
\text { ambient foliar } \\
\text { litter }\end{array}$ & 1 & $0.347 * *$ & $0.377 *$ & $0.211 *$ & $0.333^{*}$ & $0.221^{*}$ & $0.119^{*}$ \\
\hline $\begin{array}{l}\text { litter } \\
\text { decomposition } \\
\text { rate }\end{array}$ & $0.354 * *$ & $0.231 *$ & $0.332 *$ & $0.124 *$ & $0.119^{*}$ & $0.331 *$ & $0.241^{*}$ \\
\hline $\begin{array}{l}\text { lignin } \\
\text { degradation } \\
\text { rate }\end{array}$ & $0.341 *$ & 0.331 & $0.231 * *$ & 0.225 & 0.333 & $0.144 *$ & $0.155^{*}$ \\
\hline $\begin{array}{l}\text { cellulose } \\
\text { degradation } \\
\text { rate }\end{array}$ & $0.297 *$ & 0.151 & $0.177 * *$ & $0.212 *$ & $0.378 * *$ & 0.121 & $0.222 *$ \\
\hline
\end{tabular}

Significant effects: $* P<0.05 ; * * P<0.01$

decomposition. In addition, the degradation of lignin could also directly result in an increase in the potential for biotic decomposition of carbohydrates present in foliar litter (Austin and Ballaré 2010). As a result, this may also affect the degradation rates of lignin and cellulose by soil fauna, increasing decomposition time.

\section{Conclusions}

Litter degradation, including two recalcitrant components, lignin and cellulose, were evaluated in Pinus massoniana plantations under a range of canopy densities (A: 0.91, B: 0.83, C: 0.74, D: 0.62, and E: 0.49). Litter decomposition rates increased with the decreasing densities and the remaining litter mass decreased exponentially over the decomposition time. Lignin and cellulose degradation showed an exponential trend with the decomposition time, and their degradation rate was higher under mid-density canopies $\mathrm{C}$ and D. compared to the other canopy densities, The soil fauna was the main driver on litter decomposition and breakdown of its refractory compounds. We suggest that maintaining the canopy density between 0.6 and 0.7 will promote litter decomposition, including the decomposition of lignin and cellulose, which will be beneficial for the sustainable development of $P$. massoniana plantations in this region. 
Acknowledgements We are grateful to the anonymous reviewer and to the editors for their constructive comments, as well as to our team for their help with the field sampling and laboratory analyses.

Open Access This article is distributed under the terms of the Creative Commons Attribution 4.0 International License (http://crea tivecommons.org/licenses/by/4.0/), which permits unrestricted use, distribution, and reproduction in any medium, provided you give appropriate credit to the original author(s) and the source, provide a link to the Creative Commons license, and indicate if changes were made.

\section{References}

Austin AT, Ballaré CL (2010) Dual role of lignin in plant litter decomposition in terrestrial ecosystems. Proc Natl Acad Sci USA 107(10):4618-4622

Battaglia MA, Mou P, Palik B, Mitchell RJ (2002) The effect of spatially variable overstory on the understory light environment of an open-canopied longleaf pine forest. Can J For Res 32(11):1984-1991

Berg B, McClaugherty C (2008) Plant litter. Decomposition, humus formation, carbon sequestration, 2nd edn. Springer, New York

Brandt LA, King JY, Hobbie SE, Milchunas DG, Sinsabaugh RL (2010) The role of photo degradation in surface litter decomposition across a grassland ecosystem precipitation gradient. Ecosystems 13(5):765-781

Couteaux MM, Bottner P, Berg B (1995) Litter decomposition, climate and liter quality. Trends Ecol Evol 10:63-66

Cui NJ, Zhang DJ, Liu Y, Zhang J, Yang WQ, Ou J, Zhang J, Song XY, Yin R (2014) Plant diversity and seasonal dynamics in forest gaps of varying sizes in Pinus massoniana plantations. Chin J Plant Ecol 38(5):477-490

Flukes EB, Johnson CR, Wright JT (2014) Thinning of kelp canopy modifies understory assemblages: the importance of canopy density. Mar Ecol Progr Series 514(514):57-70

Fu LY, Sun H, Zhang HR, Lei XD, Lei YC, Tang SZ (2014) Effect of trunk diameter at chest height on the canopy characteristic factors of Chinese fir under different canopy density. Acta Ecol Sin 33(8):2434-2443

Guo PP, Jiang H, Shuquan YU, Yuandan MU, Dou R, Song X (2009) Comparison of litter decomposition of six species of coniferous and broad-leaved trees in subtropical China. Chin J Appl Environ Biol 15(5):655-659

He W, Wu FZ, Zhang DJ, Yang WQ, Tan B, Zhao YY (2015) The effects of forest gaps on cellulose degradation in the foliar litter of two shrub species in an alpine fir forest. Plant Soil 393(1-2):109-122

He W, Wu FZ, Yang WQ, Tan B, Zhao YY, WU QQ (2016a) Lignin degradation in foliar litter of two shrub species from the gap center to the closed canopy in an alpine fir forest. Ecosystems 19(1):115-128

He W, Wu FZ, Yang WQ, Zhang DJ, Xu ZF, Tan B, Zhao YY, Justine MF (2016b) Gap locations influence the release of carbon, nitrogen and phosphorus in two shrub foliar litter in an alpine fir forest. Sci Rep 6:22014

Herman J, Moorhead D, Berg B (2008) The relationship between rates of lignin and cellulose decay in aboveground forest litter. Soil Biol Biochem 40(10):2620-2626

Hossain MZ, Sugiyama SI (2011) Influences of plant litter diversity on decomposition, nutrient mineralization and soil microbial community structure. Grassl Sci 57(2):72-80
Li YN, Zhang BL, Qin SY, Li SY, Huang XR (2008) Research and application of canopy density and measuring method. World For Res 21(1):40-46

Lin N, Liu Y, Li GL, Lv RH, Wang SH, Hou BZ, Yin FJ (2010) Research progress of impact of thinning on plantation litter decomposition. World For Res 3:44-47

Liu MX, Shi JH, Wang XY, Peng QM (2011) Effect of canopy density and age on the function of the protection forest and the carbon sink and carbon sequestration value. J Northeast For Univ 39(6):30-32

Lu RK (1999) Soil and agrochemical analytical methods. China Agricultural Science and Technology Press, Beijing, pp 146-195 (In Chinese with English abstract)

Madsen P, Larsen JB (1996) Natural regeneration of beech (Fagus sylvatica L.) with respect to canopy density, soil moisture and soil carbon content. For Ecol Manage 97(2):95-105

Olson JS (1963) Energy storage and the balance of producer sand decomposers in ecological system. Ecology 44:322-331

Rahman MM, Tsukamoto J, Rahman MM, Yoneyama A, Mostafa KM (2013) Lignin and its effects on litter decomposition in forest ecosystems. Chem Ecol 29(6):540-553

Schwarz W (2001) The cellulosome and cellulose degradation by anaerobic bacteria. Appl Microbiol Biotechnol 56(5-6):634-649

S.F.A. (2013) [State Forestry Administration]. China's forest resources situation - eighth forest resources of national forest resources inventory. http://www.forestry.gov.cn/gjslzyqc.html

Shen WT (1995) Ecological problems and countermeasures in the development of artificial timber forest in China. World For Res $8(2): 51-55$

Simoneta NY, Carlos F, Adrianc N, Graham R, Owilliam H (2008) Decomposition and macro invertebrates in experimental litter along a secondary chronosequence of tropical montane forest. Biol Fertil Soils 44(6):853-861

Tan B, Wu FZ, Yang WQ, Zhang J, Xu ZF, Liu Y, Gou XL (2013) Population structure of soil arthropod in different age Pinus massoniana plantations. Chin J Appl Ecol 24(4):1118-1124 (in Chinese)

Tong WG, Chen SL, Zhou S, Chen D (2014) Correlative analysis between contents of nutrients and secondary substances in damaged Pinus massoniana needles and population parameters of Dendrolimus kikuchfi (Lepidoptera: Lasiocampidae). Plant Dis Pests 55(4):435-443

Tsai CC, Chang YF, Hsu CW (2011) Effects of thinning treatments on nutrient release from decomposing needle litter of Sugi (Cryptomeria japonica D. Don) in northeast-ern Taiwan. Taiwan. J Polym Res 26(2):163-177

Wall DH, Bradford MA, St Johnet MG, Trofymow JA, BehanPelletier V, Bignell DE et al (2008) Global decomposition experiment shows soil animal impacts on decomposition are climate-dependent. Glob Change Biol 14(11):2661-2677

Wang QT (2012) Study on the effect of mixed cultivation of Chinese fir Masson pine and Schimasuperba at the mountain area of Southern Fujian. J Fujian Coll For 32(4):321-325

Wu FZ, Yang WQ, Zhang J, Deng RJ (2010) Litter decomposition in two subalpine forests during the freeze-thaw season. Acta Oecol 36(1):135-140

Yi WY (2000) Pictorial keys to soil animals of china. Science Press of China

Zhang J, Liu Y, Zhang J, Ou J, Cui NJ (2014) Pinus massoniana canopy rainfall redistribution and its characteristics of nitrogen and phosphorus. Chin J Ecol 33(6):1451-1458

Zhang Y, Zhang DJ, Zhang J, Yang WQ, Deng CC, Li JP, Li X, Tang SS, Zhang MJ (2015) Effects of forest gap size on litter recalcitrant components of two tree species in Pinusmassoniana plantations. Chin J Plant Ecol 39(8):785-796 
Zhao YB, Zhang DJ, Zhang J, Zhou HY, Wei DP, Zhang J, Yuan YL (2017) Understory vegetation diversity of Pinus massoniana plantations with various canopy densities. Chin J Appl Environ Biol 02:1-10

Zhou T, Han HR, Kang FF, Chen XQ, Song YL, Liu K, Li Y (2013) Distribution characteristics of precipitation in different canopy density of Pinus tabulaeformis plantation at Taiyue Mountain area. Acta Ecol Sin 33(5):1645-1653

Zhou HY, Zhang J, Zhang DJ, Zhang J, Wei DP, Zhao YB, Zhao B, Li CB (2017) Community characteristics of soil fauna for different canopy density of a Pinus massoniana plantation. Acta Ecol Sin 37(6):1-16 